\title{
Performance Determinants of China's Internet Lending Business: A Study on the Regulated and Unregulated Companies
}

\section{Zhongkai Tian, Ahmad Fahmi Sheikh Hassan}

To Link this Article: http://dx.doi.org/10.6007/IJARBSS/v11-i11/10976

DOI:10.6007/IJARBSS/v11-i11/10976

Received: 07 September 2021, Revised: 04 October 2021, Accepted: 20 October 2021

Published Online: 04 November 2021

In-Text Citation: (Tian \& Hassan, 2021)

To Cite this Article: Tian, Z., \& Hassan, A. F. S. (2021). Performance Determinants of China's Internet Lending Business: A Study on the Regulated and Unregulated Companies. International Journal of Academic Research in Business and Social Sciences, 11(11), 65-78.

Copyright: (c) 2021 The Author(s)

Published by Human Resource Management Academic Research Society (www.hrmars.com)

This article is published under the Creative Commons Attribution (CC BY 4.0) license. Anyone may reproduce, distribute, translate and create derivative works of this article (for both commercial and non-commercial purposes), subject to full attribution to the original publication and authors. The full terms of this license may be seen at: http://creativecommons.org/licences/by/4.0/legalcode

Vol. 11, No. 11, 2021, Pg. $65-78$

Full Terms \& Conditions of access and use can be found at http://hrmars.com/index.php/pages/detail/publication-ethics 


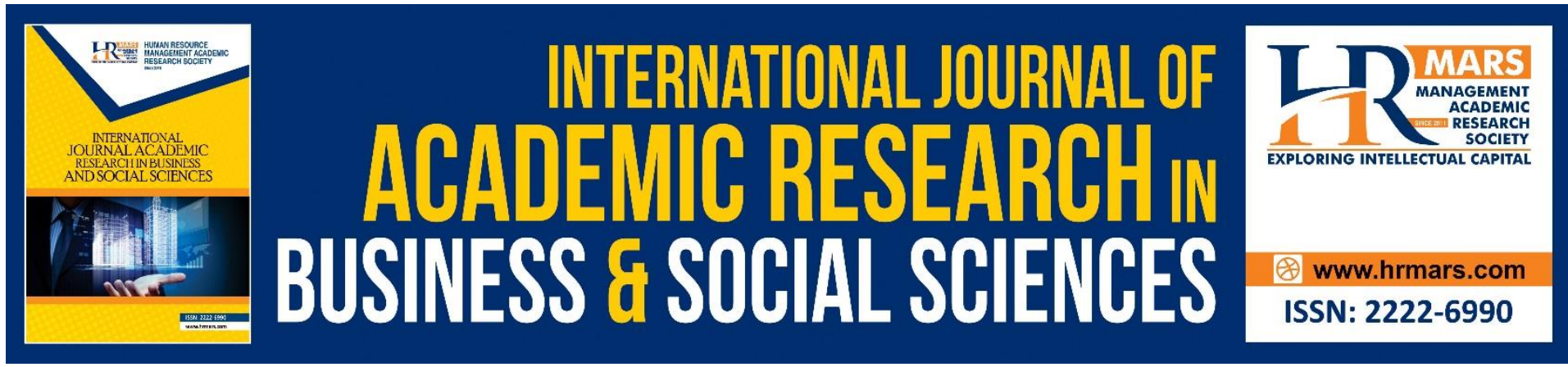

\title{
Performance Determinants of China's Internet Lending Business: A Study on the Regulated and Unregulated Companies
}

\author{
Zhongkai Tian \\ Shandong University of Political Science and Law, Jinan, China \\ Email: tianzhongkai@sdupsl.edu.cn \\ Ahmad Fahmi Sheikh Hassan \\ School of Business and Economics, Universiti Putra Malaysia, Serdang, Malaysia \\ Email: ahmadfahmi@upm.edu.my
}

\begin{abstract}
In recent years, commercial internet lending has become a major industry in China, and internet lending platforms have also begun using innovative ways to mobilize and disseminate small business capitals. However, these platforms are not well managed as there has been an increase in the number of defaults in recent years. In order to strengthen the governance of the internet lending business, China's newly established National Internet Finance Association (NIFA) has introduced some regulations aiming at reducing the risk of defaults and enhancing performance of its regulated members as a way to improve competitiveness. The objective of this study is to identify the performance determinants of China's regulated and unregulated internet lending companies. Using the binary logistic regression method, this study will investigate the differences of the two types of lending platforms through comparison. We used 343 platforms based on one-month's data so as to explore the differences. Our study provides evidence showing the existence of four performance determinants for both regulated and unregulated companies; namely, total transactions, number of investors, loan periods, and interest rates. These determinants could be used by individual investors to avoid potential risk and investment decision making while being instrumental for the policymakers when regulating this market.
\end{abstract}

Keywords: Internet Lending, Performance, Finance, China, Regulation

\section{Introduction}

With the popularity of the Internet of Things and Industry 4.0, commercial internet lending platforms have become a novelty, attracting much public attention. The emergence of Internet lending has led to the advantage of reducing the requirement for a collateral when issuing a loan, unlike traditional bank loans. This has helped many borrowers to get loans fast, and with little hassle. The internet lending platforms initiate loans by matching the lenders with borrowers who are usually small business owners and individuals. This cuts down the role of conventional banks and other financial institutions in the process. Internet lending has 
become very popular around the world including China. As a rising economic power, China is beginning to experience a new era of revolution in the financial sector which utilizes internet resources (Wei, 2015). Indeed, internet lending experienced a remarkable development in China (Nguyen et al., 2020). From the year 2012 to 2015, the number of internet lending platforms have grown from 200 to 3769 (Xu, 2017). In 2015, the internet lending volume of transactions was around US\$150 billion in China, more than ten times the amount of the lending market size in the United States (Xinhua, 2016). As an example, Credit Ease (Yi Xin), which is a leading Chinese internet lending platform from Beijing, has already overtaken the position of the U.S. internet lending platform, LendingClub, to become the world's largest internet lending platform. Both Credit Ease and LendingClub are listed on the New York Stock Exchange (NYSE). However, with the rapid development of internet lending, the default risk problems have also increased, thereby creating a large amount of losses to the internet lending participants.

To deal with the risks of internet lending, regulations must be imposed by the government because it plays a vital governance role in the development of the country's financial market and economic growth (Jin et al., 2016; Chiu, 2016; Jiang, 2016). The rise of governmental interventions had challenged the liberalism and market triumphalism of the public's management on the financial market (Or \& Aranda-Jan, 2017). The risks highlighted by the default cases had led to the government's intervention; it realised the necessity to have governance mechanisms which can help to stabilize the rapidly-growing market, and to limit the default risks, whilst not deterring innovation (Xu et al., 2019). The government of China then began imposing supervisory regulations in order to reduce the risk problems associated with the internet lending market.

The objective of this study is to compare the performance of China's regulated and unregulated internet lending business by focussing on six factors - total transactions, number of investors, interest rates, number of projects, loan periods, and alliance partners. This study utilised the operation data extracted from 343 internet lending platforms in China. The study also combined the comparison method by first comparing the variables of the platforms which include two different risk level groups followed by the use of the binary logistic regression which tests the relationships between the operational variables and the performance impact of the regulation. This study aims to contribute to the literature on China's internet lending market as current studies tend to show more of the default problems existing in internet lending (see for example Lin et al., 2016; Emekter et al., 2015). Differing slightly from the past studies, the current study will introduce several different aspects. Firstly, the dataset used in the current study involved a large number. These datasets broaden the study of the performance analysis. In contrast, previous studies had applied data sourced from only one of the large internet lending platforms in the U.S, such as the Prosper or the LendingClub (Serrano-Cinca et al., 2015; Emekter et al., 2015; Zott, \& Amit, 2010; Lin et al., 2016; Slattery et al., 2014; Gonzalez, \& McAleer, 2011). Secondly, this study analyses the performance of the internet lending platforms based on six operational factors. The results of this study will be of benefit to individual investors who can use the information to make optimal investment decisions. Individual investors could also apply the results to analyse the performance of the internet lending platforms. This study also accounts for the recent government activities such as issues on regulations and the set up of associations on China's internet lending market, both of which can provide investors with the calculated risks related to internet lending businesses. 
The remainder of this paper is structured as follows: The next section provides the literature related to internet lending and the discussion about the theoretical framework used in this study. The subsequent section describes the methodology used followed by the data analysis and results. This paper concludes with the implications.

\section{Theoretical Background}

In the United Kingdom and United States, the financial landscape of the internet lending market is controlled by large lending platforms, such as Prosper and LendingClub. This is slightly different from China which already has more than 2000 internet lending platforms in 2015, which offered internet lending services to the public (Williams-Grut, 2015). These internet lending platforms in China provide financing channels and financial services to borrowers like individuals, and small to medium-size enterprises (SMEs). Although it supports many SMEs, internet lending also brings disadvantages due to a lack of security mechanisms which can monitor the large number of financial transactions. These internet lending platforms face many risks especially when there is fraud, and when repayments cannot be met (Liu, 2015). Nonetheless, internet lending has become very popular in China.

Despite their popularity, these internet lending platforms are not very well managed in the market. For instance, defaults on loans can happen and borrowers may face difficulties repaying their loans. When this happens, the owners of the platforms are required to make up the missing amounts to the lender. In 2014, reports made by the National Busines Daily indicate that there were 231 million-yuan RMB scandals occurring in several cities like Hangzhou, Shanghai, and Shenzhen. Owners of those platforms absconded, leaving their borrowers and investors in limbo. Such a situation is happening increasingly. The default cases have been continuing for as recent as 2019, with the Chinese police getting involved and freezing the assets of more than 380 internet lending platforms for a total of about 10 billion yuan, since June 2019. This phenomenon had created a crisis for both the borrowers and lenders. The proliferation of such internet lending irregularities had raised concerns about the social panic affecting platform users and borrowers. This occurrence eventually attracted the attention of the government which then strived to look for resolutions to overcome those issues. These plans also include a rescue plan strategy (Wei, 2015).

With so many internet lending platforms available, there is thus a need for them to remain competitive. Some of these platforms offer competitive interest rates. This means that they can attract more investors, however, they are also taking more risks (Emekter et al., 2015). It was observed by Geng et al. (2016) that interest rates can be positively correlated with financial risks. This implies that interest rates reflect the capabilities of risk control. By far, interest rates has remained to be one of the many measures taken by businesses to measure their competitiveness with others. Interest rates seem to be an essential factor for the internet finance platforms because interest rates can help these finance platforms to attract more investors, like attractive or innovative goods attracting more customers. To strengthen their positions in the market, most internet finance platforms thus engage alliance partners to boost their credibility or reputation.

The competitive strategies developed and implemented by the internet finance platforms also come with challenges. For example, high interest rates may mean higher return programs, thus borrowers risk paying more. Consequently, they may default payments (Kar \& Swain, 2014). Nonetheless, such programs allow investors to identify the default risk levels, thereby allowing them to take the necessary precautions. 
In the financial and online business sectors, researchers tend to focus on total transactions, and the number of customers, as variables for operation (Mishra et al., 2019; Chen et al., 2018; Panniello et al., 2016). These variables were thus considered for the purpose of assessing the effectiveness of the measures taken to assess the financial sector, and the credibility of the regulations. This is because firm information measures were required under the regulations of the internet finance industry. In the internet lending environment, factors such as loan periods, and the number of loan projects, can vary between one internet finance platform to another (Chen et al., 2019). The first factor, loan periods, would test for investment period preference of the investors (i.e. short-term vs. long-term period); the second factor, number of loan projects is related to the investment choices provided to investors. Investors may use the information generated from the above variables to evaluate the internet lending platforms.

The policies implemented by the government may influence the economic system's formulation and the incentives structure, and it might even affect the quality (Lin, 2008). China's financial market governance relies on the government's policies and regulations to control the risks of the financial market (Yang, 2019). From the perspective of the supervisory authorities, a standardized risk regulation indicator system ought to be formulated for the Internet financial market. This can be used to calculate various warning intervals, warning lines and warning points, according to the actual situation of Internet finance. The financial supervision measures were intended for predicting and warning the different levels of market risks of the Internet financial, and also to propose ways for dealing with the crisis. In relation to this, the National Internet Finance Association of China (NIFA) is a self-regulatory national organization that specializes in internet lending. It was formed based on the initiative of the People's Bank of China. The NIFA was developed in cooperation with relevant commissions and ministries, including the China Banking Regulatory Commission (CBRC), the China Insurance Regulatory Commission (CIRC), and the China Securities Regulatory Commission (CSRC). On July 18, 2015, the People's Bank of China, the CBRC, CSRC, CIRC, and 10 other ministries and commissions, jointly issued a guidance which could be used to stimulate the development of internet lending in healthy ways (issued in 2015, no. 221). This was approved by the State Council, the Ministry of Industry and Information Technology, the Central Committee of the Communist Party of China, the State Administration for Industry and Commerce, and the Ministry of Public Security. Based on these observations, the following hypotheses were formulated:

$\mathrm{H} 1$ : There is a difference in the performance of China's regulated and unregulated internet lending business.

$\mathrm{H} 2$ : There is a difference in the interest rates of China's regulated and unregulated internet lending business.

H3: There is a difference in the loan periods of China's regulated and unregulated internet lending business.

$\mathrm{H} 4$ : There is a difference in the number of loan projects of China's regulated and unregulated internet lending business.

$\mathrm{H} 5$ : There is a difference in the alliance partners of China's regulated and unregulated internet lending business.

H6: There is a difference in the total transaction of China regulated and unregulated internet lending business.

H7: There is a difference in the number of investors of China's regulated and unregulated internet lending business. 


\section{Research Objective, Methodology and Data}

The objective of this study is to identify the performance determinants of China's regulated and unregulated internet lending companies. The NIFA is of great importance as the first industrial committee with special functions that focussed on the behaviors of internet lending at the national level in China. The NIFA aims to regulate the market behavior of institutions, protect the interests and legitimate rights of the industry, promote professional institutions towards contributing more effectively to social and economic development, and to guide the compliance and healthy performance of the industry. This is done through membership service and regulatory management. The institutional members of NIFA includes almost all types of service and mainstream businesses on the internet, such as internet lending and crowdfunding. Development of clusters, such as members of the internet lending platforms under NIFA, could support competitiveness and foster industry approaches in modern industrial policies (Stichhauerova et al., 2020). In light of the governance role which the NIFA has over the internet financing business in China, we thus view the members of NIFA as regulated internet platforms, whose potential default risks should be low.

To investigate the differences in the factors between the two types of internet lending platforms, a binary logistic regression and pairing method (see for example Beaver, 1966; Altman et al., 1977; Takahashi et al., 1984) was applied in the selection of the population. This empirical study focused on using data which were extracted from the internet lending platforms in China. The datasets which were secondary data contexts, were then used to test the comparison. These secondary data were extracted from public information disclosures posted on the WDZJ.com, a third-party website. The data were deemed to be cross-sectional. They included all the information that had been seen by potential investors when making their money-lending decisions. In this study, data were collected in June 2018. A comparison of the data, three years after the regulation was issued, could reflect differences on the performance of China's regulated and unregulated internet lending business. The data collected comprised platform and operational information. The total number of lending platforms involved in this study were 343, of which 160 platforms were from NIFA and the other 183 were normal platforms.

This study investigates six individual variables: total transactions (TT), number of investors (NI), interest rates (IR), number of projects (NP), loan periods (LP), and alliance partners (AP). In this study, total transactions and number of investors were factors used to illustrate the performance of the internet lending platforms. Total transactions refer to the total amount of funds (principal) of all the financing activities that had actually occurred, from the time the platform started operations, with monthly updates. Total transactions reflected the internet lending industry's transaction volume. This information can be acquired from the internet lending platform's websites directly. Total transactions also reflected the active situation of the internet lending industry. It is an important measure of an internet lending platform's performance. Total number of transactions can be defined as the total number of financing projects that have been successfully financed by the platforms since the platforms began operations. Total number of investors was defined as the total number of successful investors operating on the successful internet lending platform, from the time the platform started operations, with at least one monthly update.

The interest rate offered to investors was measured as an important piece of operational information that differentiates one internet lending platform from another. The returns to investors would directly be influenced by a high or low interest rate. The interest rate would stand as the average yield rate that retail investors absorbed as lenders. Although there were 
various interest rates on the internet lending platforms, based on specific projects, the average interest rates were also available on the websites. In this study, the average interest rates were utilized for measuring the firm's competitive strategies, and also the independent variables. The loan periods were calculated as the project's average loan period on the internet lending platform. The number of projects referred to the projects provided by the internet lending platform for investors. On the other hand, the number of projects would reflect the internet lending platforms which provided investment choices to the individual investors. The alliance partners were measured as the number of alliance partners in an internet lending platform. Alliance partners were disclosed on every internet lending platform. In this study, the number of alliance partners was used as a factor to measure the internet lending platform's alliance situation.

\section{Data Analysis}

This section first describes and summarize the descriptive statistics of the data, followed by the results of the analysis made through the comparison of the binary logistic regression method. Table 1 and Table 2 below illustrate the descriptive statistics of the regulated and unregulated groups' data in relation to the six variables used respectively. In the comparison of the regulated and unregulated groups, it was found that the range from the unregulated groups was higher than that of the regulated groups, except for TT. From the descriptive statistics shown in both tables, it can also be noted that the mean values for each variable, except IR, of the regulated groups were higher than the mean values of the unregulated groups. Meanwhile, the standard deviation for the two groups varied.

Tab. 1- Descriptive statistics for the regulated group's data. Source: own research

\begin{tabular}{lllllll}
\multicolumn{2}{l}{ Regulate } & \multicolumn{2}{l}{ Minimu } & & \multicolumn{2}{l}{ Std. } \\
d & Range & $\mathrm{m}$ & Maximum & Mean & Deviation & \\
\hline TT & 139.40 & 0.317 & 139.72 & 14.64 & 255.90 & 654.88 \\
NI & 2337 & 2 & 2339 & 316.73 & 501.51 & 251.51 \\
LP & 29.53 & 1.56 & 31.09 & 7.49 & 6.72 & 45.11 \\
NP & 248.11 & 3 & 251.11 & 139 & 459.79 & 211.41 \\
IR & 12.37 & 5.06 & 17.43 & 9.28 & 2.16 & 4.67 \\
AP & 19 & 0 & 19 & 3.76 & 3.49 & 12.18 \\
\hline
\end{tabular}

Tab. 2 - Descriptive statistics for the unregulated group's data. Source: own research

\begin{tabular}{lllllll}
\hline $\begin{array}{l}\text { Unregulat Range } \\
\text { ed }\end{array}$ & $\begin{array}{l}\text { Minimu } \\
\mathrm{m}\end{array}$ & Maximum & Mean & $\begin{array}{l}\text { Std. } \\
\text { Deviation }\end{array}$ & Variance \\
\hline TT & 577.56 & 0.74 & 577.63 & 19.20 & 44.16 & 195.05 \\
$\mathrm{NI}$ & 4005 & 13 & 4018 & 538.22 & 234.41 & 54.94 \\
LP & 35.63 & .11 & 35.74 & 5.53 & 5.24 & 27.51 \\
NP & 1334.07 & 10 & 1344.07 & 583.76 & 72.75 & 529.28 \\
IR & 15.70 & 5.76 & 21.46 & 11.14 & 2.69 & 7.25 \\
AP & 66 & 0 & 66 & 6.07 & 5.993 & 35.92 \\
\hline
\end{tabular}

\section{Results and Discussion}

Additionally, the independent sample test was conducted to determine the difference between the two groups. Two results were generated from two different t-tests-one was 
based on the equal variance while the other was based on the unequal variance. The result to be used would depend on the result extracted from Levene's test. If the p-value of Levene's test was above 0.05 , it can be viewed that the variance of the two groups was the same. On the other hand, if the p-value of Levene's test was less than 0.05 , then the two groups were viewed as having "unequal variance". The null hypothesis for this comparison method is that the two groups were equal.

Tab. 3- Testing results for the regulated and unregulated groups: Source: own research

\begin{tabular}{|c|c|c|c|}
\hline & & $\begin{array}{l}\text { Levene's Test for } \\
\text { Equality of variance } \\
\text { (Sig.) }\end{array}$ & $\begin{array}{l}\text { t-test for Equality of } \\
\text { means (Sig.) }\end{array}$ \\
\hline \multirow[t]{2}{*}{ TT } & Equal Variances & \multirow[t]{2}{*}{.000} & .000 \\
\hline & Not Equal Variances & & .001 \\
\hline \multirow[t]{2}{*}{$\mathrm{NI}$} & Equal Variances & \multirow[t]{2}{*}{.000} & .000 \\
\hline & Not Equal Variances & & .000 \\
\hline \multirow[t]{2}{*}{ LP } & Equal Variances & \multirow[t]{2}{*}{.072} & .004 \\
\hline & Not Equal Variances & & .021 \\
\hline \multirow[t]{2}{*}{ NP } & Equal Variances & \multirow[t]{2}{*}{.248} & .411 \\
\hline & Not Equal Variances & & .250 \\
\hline \multirow[t]{2}{*}{ IR } & Equal Variances & \multirow[t]{2}{*}{.004} & .000 \\
\hline & Not Equal Variances & & .000 \\
\hline \multirow[t]{2}{*}{$A P$} & Equal Variances & \multirow[t]{2}{*}{.007} & .100 \\
\hline & Not Equal Variances & & .000 \\
\hline
\end{tabular}

Based on the testing result shown in Table 3 above, we found that the variables TT, NI, and IR were significantly different in the two groups, based on Levene's test of below 0.05 and t-test of below 0.05 , from the unequal variance assumption. For variable LP, Levene's test was 0.072 , hence it can be assumed that the variance of the two groups was the same. Meanwhile, the "equal variance" result of variable LP was 0.004 , thus the null hypothesis was not rejected. For this reason, it was concluded that there was a difference between the mean score of variable LP, at the $5 \%$ level of significance. Hence, we concluded that the variables TT, NI, IR, and LP were significantly different between the regulated and unregulated groups.

Based on the above results, the variables TT, NI, LP, and IR were noted to convey a significant difference between the unregulated group and the regulated group. In contrast, variables NP and AP showed no significant difference between these two groups. Therefore, variables TT, $\mathrm{NI}, \mathrm{LP}$, and IR were concluded to be different between the regulated and unregulated groups on the internet lending platforms.

After the four variables of $\mathrm{TT}, \mathrm{LP}, \mathrm{NI}$, and IR were identified to be significantly different between the unregulated group and the regulated group, we then compared how these four variables differed. The results are further presented in Table 4 and Table 5 below. 
Tab. 4- Statistics for the regulated group's data. Source: own research

\begin{tabular}{lllllll}
\multicolumn{2}{l}{ Regulate } & & Minimu & & & \multicolumn{2}{l}{ Std. } & Variance \\
$\mathrm{d}$ & Range & $\mathrm{m}$ & Maximum & Mean & Deviation & \\
\hline TT & 139.40 & 0.317 & 139.72 & 14.64 & 255.90 & 654.88 \\
NI & 2337 & 2 & 2339 & 316.73 & 501.51 & 251.51 \\
LP & 29.53 & 1.56 & 31.09 & 7.49 & 6.72 & 45.11 \\
IR & 12.37 & 5.06 & 17.43 & 9.28 & 2.16 & 4.67 \\
\hline
\end{tabular}

Tab. 5- Statistics for the unregulated group's data. Source: own research

\begin{tabular}{lllllll}
\multicolumn{2}{l}{$\begin{array}{l}\text { Unregulat Range } \\
\text { ed }\end{array}$} & $\begin{array}{l}\text { Minimu } \\
\mathrm{m}\end{array}$ & Maximum & Mean & $\begin{array}{l}\text { Std. } \\
\text { Deviation }\end{array}$ & Variance \\
\hline $\mathrm{TT}$ & 577.56 & 0.74 & 577.63 & 19.20 & 44.16 & 195.05 \\
$\mathrm{NI}$ & 4005 & 13 & 4018 & 538.22 & 234.41 & 54.94 \\
$\mathrm{LP}$ & 35.63 & .11 & 35.74 & 5.53 & 5.24 & 27.51 \\
$\mathrm{IR}$ & 15.70 & 5.76 & 21.46 & 11.14 & 2.69 & 7.25 \\
\hline
\end{tabular}

A comparison showed that the range was smaller for NI, LP, IR in the regulated group. This suggests that the platforms in the NIFA concentrated on operational strategies. We also found the mean of the variables in the regulated group to be higher than those in the unregulated groups, except for variable IR. This implies that the unregulated group had a high interest rate for investors which also brought higher risks for investors. The high interest rate for the unregulated groups, however, did not bring high total transactions. This indicates that investors were not pursuing high returns in internet lending activities because they may have realized the high potential risks incurred by the high interest rates.

To further explore the exact effect of the difference of each variable in the two groups, we used the binary logistic regression which contains all the variables needed for investigation, such that $p$ represents the probability of the difference. The regression model used is stated below:

$$
\operatorname{logit}(p)=\log \left(\frac{p}{1-p}\right)=\beta_{0}+\beta_{1} T T+\beta_{2} N I+\beta_{3} L P+\beta_{4} N P+\beta_{5} I R+\beta_{6} A P+e
$$

We performed binary logistics regression with TT, NI, LP, NP, IR AP served as the explanatory variables and the dummy variable (regulated and unregulated) as the outcome variable. The testing results contributed the odds that explanatory variables were the predictors for predicting the outcome variable, as illustrated in Table 6 below.

Tab. 6- Model summary. Source: own research

\begin{tabular}{|c|c|c|c|c|}
\hline Ste & $\begin{array}{l}-2 \\
\text { likelihood }\end{array}$ & Log & $\begin{array}{l}\text { Cox \& Snell R } \\
\text { Square }\end{array}$ & $\begin{array}{l}\text { Nagelkerke } \\
\text { Square }\end{array}$ \\
\hline 1 & $250.264^{a}$ & & .175 & .350 \\
\hline
\end{tabular}

The above table provides the -2loglikelihood and the pseudo $\mathrm{R}^{2}$ values for the full model. The - 2loglikelihood (250.264) was then compared to the -2loglikelihood of the null model, and the outcome showed that the new model (with the explanatory variables) had significantly, provided a better fit than the null model. This is because there was a significant decrease in the -2 loglikelihood. The $\mathrm{R}^{2}$ values indicated approximately how much variation in the 
outcome was explained by the model. Meanwhile, the Nagelkerke's $\mathrm{R}^{2}$ suggested that the predictor explained roughly $35 \%$ of the variation in the performance.

Tab. 7-Variables in the equation. Source: own research

\begin{tabular}{lllllll} 
& $\beta$ & S.E. & Wald & df & Sig. & Exp $(\beta)$ \\
\hline TT & .519 & .000 & 22.496 & 1 & .000 & 1.000 \\
NI & .024 & .000 & 5.147 & 1 & .023 & 1.000 \\
LP & .099 & .039 & 6.354 & 1 & .012 & 1.104 \\
NP & .000 & .000 & .014 & 1 & .906 & 1.000 \\
IR & .319 & .085 & 13.969 & 1 & .000 & 1.376 \\
AP & -.001 & .032 & .001 & 1 & .981 & .999
\end{tabular}

Table 7 highlights the contributions of each predictor in the full model where variables with $p$ values of less than 0.05 were deemed to have contributed significantly to the predictive ability of the model (see Greenland, et al., 2016). Based on this, four variables, namely TT with $\mathrm{p}=.000, \mathrm{NI}$ with $\mathrm{p}=.023$, AP with $\mathrm{p}=.012$, and IR with $\mathrm{p}=.000$, were observed to have significant effects on the probability of difference. Nonetheless, NP and AP, with $p=0.906$ and 0.981 , respectively, carried no significant impact on the probability of difference. In computing the probabilities of cases falling into a specific category, the B values for TT, NP, IR, AP were also noted to be all significant and positive, indicating that increasing the influence would increase the odds of difference. However, $\beta$ coefficient for NP and AP were not significant. As for AP, the $\beta$ was observed to be negative, indicating that decreasing the influence would decrease the odd of difference to some extent. The $\operatorname{Exp}(\beta)$ values, otherwise known as odd ratios, for each of our independent variables would show an increase or decrease if the ratio was greater than one or less than one, respectively (Tabachnick \& Fidell, 2001). The Exp ( $\beta$ ) values from Table 7 showed that they were clearly greater than one, thereby indicating that they have higher odds for the predictors, namely $\mathrm{TT}, \mathrm{NI}, \mathrm{AP}, \mathrm{IR}$ and the dependent variable probability of the difference of internet lending platforms. Therefore, variables $\mathrm{TT}, \mathrm{NI}, \mathrm{AP}$, and IR values have greater odds of predicting the dependent variable probability of the difference than other predictors. Meanwhile, NP and AP clearly indicated that they have a weak relationship with the dependent variable of probability of the difference.

The above results demonstrated that variables TT, NI, LP, and IR were significantly different between the two groups. The regulated groups were from the national self-regulatory organization (NIFA), specializing in the field of internet lending. Members of the NIFA experienced more rigidity imposed by the regulations of the NIFA, making it tougher for them to operate. Nevertheless, the variables that differed between the regulated and the unregulated group generated a greater performance of the variables in the disclosed operation information. The results of the current study showed that the performance of variables $\mathrm{TT}$ and $\mathrm{NI}$ could be identified by the individual investors when making investing decisions. Other variables, such as LP and IR, to be derived from the operations information, would also help investors to avoid potential risks when making decision on choosing reliable performance companies. 
Other variables, such as NP and AP, were found to be not significantly different between the regulated and unregulated groups. This result suggests that individual investors were not influenced by the number of loan projects, and the alliance partners displayed by the internet lending platforms.

The results of this study showed that four variables were significantly different between the regulated and unregulated groups of the internet lending platform. This implies that investors paid more attention to variables such as $\mathrm{TT}, \mathrm{NI}, \mathrm{LP}$, and IR from the internet lending platforms when analysing their disclosed information. Investors usually pursue high interest rate returns when making investment decisions, but high interest rates were usually related to higher potential risks of default. The high interest rates paid by the internet lending platforms would create a high operations pressure for the platforms because these platforms have to get higher returns in order to pay the investors. This situation may come with a higher risk of default at the same time. Based on the comparison statistics displayed earlier in the study, it can be said that the interest rate data from the unregulated group was higher than the regulated group. To avoid losses from platform defaults, individual investors should hesitate in making investments in internet lending platforms that provide very high interest rate returns. Beside this, investors could also analyse other variables, such as total transactions, number of investors, and loan periods so as to make sure that the internet lending platforms have a lower potential risk of defaults.

\section{Conclusions}

The emergence of internet lending can help borrowers to resolve their financial difficulties, and unequivocally challenge the traditional bank loan market. With an increasing trend of epayment, the health development of internet lending businesses is of paramount importance. A healthy internet lending platform would ensure the nation's financial system sustainability amid the current concerns about the potential unethical practices happening, and the defaults which might occur, hence affecting the contracting parties. This study has provided evidence to show that the four key determinants of the internet lending platforms' performance can be attributed to total transactions, number of investors, loan periods, and interest rates. In this regard, internet lending platforms should pay attention to these determinants for the purpose of enhancing their performance. With the rapid spread of internet lending, there may be some problems that could cause huge losses to lenders and borrowers. There is no doubt that a platform with good performance would attract a large number of users, resulting in higher level of transactions. Nonetheless, such good performance does not mean that investors were not at risk. This study highlights that investors should concentrate on these specific variables so as to evaluate their potential risks when choosing which internet lending platforms to invest in. Investors could balance the risks and returns before making investment decisions. The variables identified from this study provided evidence showing the information difference between the two groups of internet lending platforms. Regulators can make use of this information to intensify their efforts in monitoring these variables so as to prevent market defaults. According to the analysis of the performance of internet lending in the context of China, some characteristics still need to be supervised by the regulatory authorities. It is therefore suggested that the related government department, and the internet lending industry introduce more standards and mechanisms on risk control via these key determinants. In contrast, it is important that investors be aware of the risks arising from internet lending; they may need to work with the government so as to promote a healthy development of the Internet lending business. 
Indeed, this collaboration would require long-term efforts from both the public and regulators in order to make the internet lending business of China more efficient, thereby stimulating its economic growth.

This paper explored six operational factors as the determinants for internet lending platforms' performance in China. The results showed that total transactions, number of investors, loan periods, and interest rates are significantly different between the regulated and unregulated groups of the internet lending platform. These four determinants have also been emphasized in the competitive strategies theory of the business sector including for the internet lending business. The results of this study will benefit individual investors in arriving at optimal investment decisions and when analysing the performance of the internet lending platforms. This study also accounts for the recent government activities on China's internet lending market, which can provide investors with the calculated risks related to internet lending businesses.

\section{Future Studies}

In investigating the performance of the internet lending market in China, this study only examined the variables that were related to the performance of the two groups on China's internet lending platforms, i.e. the regulated and unregulated groups. This study had omitted examining how these variables may influence risks in the long term. The reason is because the available data cannot be tracked until the internet lending platform defaults occur. Future research may track a longer period of data and consider this aspect of the study with more details.

\section{References}

Altman, E. I., Haldeman, R. G., \& Narayanan, P. (1977). ZETA analysis a new model to identify bankruptcy risk of corporations. Journal of Banking and Finance, 1(1), 29-54.

Beaver, W. H. (1966). Financial Ratios as Predictors of Failure. Journal of Accounting Research, 4, 71-111.

Chen, C. W., Dong, M. C., Liu, N., \& Sriboonchitta, S. (2019). Inferences of default risk and borrower characteristics on P2P lending. The North American Journal of Economics and Finance, 50, 101013.

Chen, J. S., Weng, H. H., \& Huang, C. L. (2018). A multilevel analysis of customer engagement, its antecedents, and the effects on service innovation. Total Quality Management \& Business Excellence, 29(3-4), 410-428.

Chiu, W. H. (2016). Political governance and economic growth: Evidence from emerging economies. International Journal of Economic Perspectives, 10(4), 376-394.

Emekter, R., Tu, Y., Jirasakuldech, B., \& Lu, M. (2015). Evaluating credit risk and loan performance in online Peer-to-Peer (P2P) lending. Applied Economics, 47(1), 54-70. https://doi: 10.1080/00036846.2014.962222.

Geng, Z., Grivoyannis, E., Zhang, S., \& He, Y. (2016). The effects of the interest rates on bank risk in China: A panel data regression approach. International Journal of Engineering Business Management, 8, 1-7.

Gonzalez, L., \& McAleer, K. (2011). Online social lending: A peak at U.S. Prosper \& U.K. Zopa. Journal of Accounting, Finance and Economics, 1(2), $26-41$.

Greenland, S., Senn, S. J., Rothman, K. J., Carlin, J. B., Poole, C., Goodman, S. N., \& Altman, D. G. (2016). Statistical tests, $P$ values, confidence intervals, and power: a guide to 
misinterpretations. European Journal of Epidemiology, 31(4), 337-350. http://doi:10.1007/s10654-016-0149-3.

Jiang, B. (2016). Financial repression, financial legal governance and economic growth in China. Frontiers of Law in China, 11(1), 86-122. http:// doi:10.3868/s050-005-0160006-3.

Jin, X., Lei, G., \& Yu, J. (2016). Government governance, executive networks and enterprise R\&D Expenditure. China Journal of Accounting Research, 9(1), 59-81.

Kar, A. K., \& Swain, R. B. (2014). Interest rates and financial performance of microfinance institutions: Recent global evidence. The European Journal of Development Research, 26(1), 87-106.

Lin, X., Li, X., \& Zheng, Z. (2016). Evaluating borrower's default risk in peer-to-peer lending: evidence from a lending platform in China. Applied Economics, 49(35), 3538-3545. http://doi: 10.1080/00036846.2016.1262526

Lin, Y. F. (2008). Economic development and transition: thought, strategy and viability, Peking University Press. Beijing (in Chinese).

Liu, M. (2015). Internet finance and regulation in China. Fung Global Institute.

Mishra, S., Ewing, M.T., \& Pitt, L. F. (2019). The effects of an articulated customer value proposition (CVP) on promotional expense, brand investment and firm performance in B2B markets: A text based analysis. Industrial Marketing Management, 10, 1-12.

Nguyen, D. D., Dinh, H. C., \& Nguyen, D. V. (2020). Promotion of fintech application for the modernization of banking-finance system in Vietnam. Journal of Asian Finance Economics and Business, 7(6), 127-131.

Or, N. H. K., \& Aranda-Jan, A. C. (2017). The Dynamic Role of State and Nonstate Actors: Governance after Global Financial Crisis. Policy Studies Journal, 45(S1), S67-S81. http://doi:10.1111/psj.12201.

Panniello, U., Gorgoglione, M., \& Tuzhilin, A. (2016). Research Note-In CARSs We Trust: How Context-Aware Recommendations Affect Customers' Trust and Other Business Performance Measures of Recommender Systems. Information Systems Research, 27(1), 182-196. http://doi:10.1287/isre.2015.0610

Serrano-Cinca, C., Gutierrez-Nieto, B., \& Lopez-Palacios, L. (2015). Determinants of Default in P2P Lending. PLoS One, 10(10), e0139427. http://doi:10.1371/journal.pone.0139427

Slattery, C. R., Carter, C. M., \& Mach, T. L. (2014). Peer-to-peer lending to small businesses. Finance and Economics Discussion Series, 50(96), 945-975.

Stichhauerova, E., Zizka, M., \& Pelloneova, N. (2020). Comparison of the Significance of Clusters for Increasing Business Performance. Journal of Competitiveness, 12(3), 172189. https://doi.org/10.7441/joc.2020.03.10

Tabachnick, B. G., Fidell, L. S. (2001). Using Multivariate Statistics. 4th Edition, Allyn and Bacon, Boston.

Takahashi, K., Kurokawa, Y., Watase, K. (1984). Corporate bankruptcy prediction in Japan. Journal of Banking and Finance, 8(2), 229-247.

Wei, S. (2015) Internet lending in China: Status quo, potential risks and regulatory options. Computer Law \& Security Review 31: 793-809.

Williams-Grut, O. (2015). There's another Chinese market growing explosively - and Beijing wants to take control before it "blows up." Business Insider UK. Available via. http://uk.businessinsider.com/china-regulate-peer-to-peer-and-internet-finance2015-8. 
Xinhua. (2016). China's online P2P lending almost quadrupled in 2015: report. Available via Xinhua. http://news.xinhuanet.com/english/2016-01/02/c_134970571.htm.

Xu, D., Tang, S. \& Guttman, D. (2019). China's campaign-style Internet finance governance: Causes, effects, and lessons learned for new information-based approaches to governance. Computer Law \& Security Review, 35, 3-14.

Xu, J. (2017). China's Internet Finance: A Critical Review. China \& World Economy, 25(4), 7892.

Yang, J. (2019). Analysis of the government's comprehensive governance of the financial market in the internet age. Advances in Economics, Business and Management Research, 91.

Zott, C., \& Amit, R. (2010). Business model design: An activity system perspective. Long Range Planning, 43, 216-226. 